\title{
I-MONSUN : FUTURE MODEL OF SUSTAINABLE ENTREPRENEURSHIP ECO- SPHERE IN CREATIVE ECONOMY
}

\author{
NIK ZULKARNAEN KHIDZIR* \\ ABU HASSAN HASBULLAH** \\ KHAIRUL AZHAR MAT DAUD*** \\ AHMAD RASDAN ISMAIL*** \\ SURIATINI ISMAIL*****
}

\begin{abstract}
Abstrak
Ekonomi kreatif menjadi agenda penting pada abad ke-21 di seluruh dunia untuk mewujudkan lebih banyak peluang perniagaan dan meningkatkan pasaran kerja dalam industri. Fakulti Teknologi Kreatif dan Warisan melangkah ke hadapan dengan memperkenalkan I-Monsun, sebuah organisasi berasaskan keuntungan untuk memangkinkan pembangunan ekonomi kreatif di negara melalui model masa depan Lestari Keusahawanan Ecosphere (FTKW-SEE). Inisiatif ini merupakan pelan strategik lestari bagi merangsang pembangunan keusahawanan di kalangan graduan FTKW yang berpengetahuan dan berkemahiran. Disamping itu, ianya diharap mampu mewujudkan pasaran kerja dan membentuk ekonomi kreatif yang lebih mampan. Secara amnya Model FTKW-SEE membentuk beberapa kitaran lengkap penjanaan pendapatan dan platform keusahawanan yang lestari melalui dua entiti bersepadu utama iaitu Monsun Industri dan Monson Academy. Kedua-dua entiti utama ini menjadi pemangkin kearah mewujudkan Model FTKW-SEE yang lengkap (1: Innovation, Creativity and Entrepreneurship (ICE); 2: Student In Free Enactus (SIFE) dan 3: Entreprenuership and Regenerative Economy Enterprises (ERE). Monsun Industri memberi fokus kepada pembangunan dan pengkomersialan produk dan perkhidmatan dalam dan luar negara bagi menjana pendapatan. Pada masa yang sama, Monsun Industries juga berfungsi sebagai platform transit bagi bakal graduan FTKW menjalani Latihan Industri mereka. Manakala kepada graduan FTKW, ianya berfungsi sebagai Inkubator untuk aktiviti-aktiviti keusahawanan dalam industri kreatif. Sementara itu, Monsun Akademi memberi tumpuan kepada mana-mana aktiviti pendapatan yang dijana menerusi sektor pendidikan dan latihan dalam pasaran tempatan dan antarabangsa. Monson Akademi akan menawarkan kursus diploma dan menyelaras pentauliahan sijil kemahiran kepada beberapa kolej komuniti, IKBN dan Desa Ukir Kayu (DUK) yang berada di sekitar Lembah Monsun. Dalam usaha melestarikan dan mengukuhkan perniagaan dan rangkaian keusahawanan di persada antarabangsa, perkembangan teknologi maklumat komunikasi masa depan juga diambil kira dengan mewujudkan platform maya seperti CIN.my, HIN.my dan MIN.my. Platform maya ini juga dihubungkan dengan rangkaian industri antarabangsa lain yang diiktiraf di seluruh dunia. Selari dengan matlamat fakulti dan universiti, kertas kerja ini membincangkan mekanisma penting yang membentuk model masa depan FTKW Sustainable Entreprenourship Ecosphere
\end{abstract}


(FTKW-SEE) dan bagaimana model ini boleh memberi manfaat kepada Universiti Malaysia Kelantan khususnya kepada FTKW, pembangunan modal insan, ekonomi industri kreatif dan penjenamaan universiti.

Kata Kunci: Kelestarian, Kreatif Ekonomi, Teknologi, Keusahawanan, Pengkomersilan

* PhD dan Timbalan Dekan di Fakulti Teknologi Kreatif dan Warisan, Universiti Malaysia Kelantan (UMK).

** PhD, Profesor dan Dekan di Fakulti Teknologi Kreatif dan Warisan, Universiti Malaysia Kelantan (UMK).

*** PhD dan Timbalan Dekan di Fakulti Teknologi Kreatif dan Warisan, Universiti Malaysia Kelantan (UMK).

**** PhD, Profesor Madya dan Ketua Unit Pengurusan Persekitaran, Keselamatan Dan Kesihatan Pekerjaan UMK.

***** PhD dan Ketua Program Senibina \& Ekistiks di Teknologi Kreatif dan Warisan, Universiti Malaysia Kelantan (UMK). 


\begin{abstract}
Creative economy become focus agenda in 21st century around the world to create more business opportunities and prosperity in the job market in the industry. Faculty Creative Technology and Heritage started their another initiative one step further to introduce I-Monsun, it's private wing to catalyse creative economy development in the country through future model of Sustainable Entrepreneurship Ecosphere (FTKW-SEE). The initiative is our strategic plan to encourage FTKW graduates to become knowledgeable and skilful entrepreneurs, able to meet the demands of the job market and contribute in shaping the creative economy. This sustainable model proposed a complete cycle of income generator and entrepreneurship platform through two major integrated entities (Monsun Industries and Monson Academy) to form the entire complete ecosphere models (1: Innovation, Creativity and Entrepreneurship (ICE); 2: Student In Free Enactus (SIFE) and 3: Entreprenuership and Regenerative Economy Enterprises (ERE). Monsun Industries concentrate on products and professional services commercialization, both locally and globally, to generate profits for FTKW, UMK. Monsun Industries aim to serve as transit platforms for FTKW Student Industrial Training playground and also an Incubator to starts entreprenourial activities after the students graduate. Meanwhile, Monsun Academy focuses on educational and training-related activities that are capable to generate income for local and international markets. Monson Academy will offer diploma couses and coordinate skill certifications to several community colleges, IKBN and DUK which are known as the community of Monsun Valley. Additionally, to strengthen the business and entrepreneurial networking through future advanced information communication technology virtual platforms such as CIN.my, HIN.my and MIN.my will be developed. These virtual platforms are also connected to other recognized international industrial networks around the globe. Therefore, this paper intentionally discusses the future model and entities of FTKW Sustainable Entrepreneurship Ecospehere and how the model can benefit the FTKW-UMK on its human capital development, creative industries and professional branding of the university.
\end{abstract}

Keywords: Sustainable, Creative Economy, Technology, Entrepreneurship, Commercialization

\footnotetext{
* PhD dan Timbalan Dekan di Fakulti Teknologi Kreatif dan Warisan, Universiti Malaysia Kelantan (UMK).

** PhD, Profesor dan Dekan di Fakulti Teknologi Kreatif dan Warisan, Universiti Malaysia Kelantan (UMK).

*** PhD dan Timbalan Dekan di Fakulti Teknologi Kreatif dan Warisan, Universiti Malaysia Kelantan (UMK).

**** PhD, Profesor Madya dan Ketua Unit Pengurusan Persekitaran, Keselamatan Dan Kesihatan Pekerjaan UMK.

***** PhD dan Penyelaras Program Senibina \& Ekistik di Teknologi Kreatif dan Warisan, Universiti Malaysia Kelantan (UMK).
} 


\subsection{Introduction}

The fastest growing businesses in the world today are the ones involved in the entire value chain of creative industry. Now is the right moment for every player of creative industry, universities and goverment to participate and invest in Creative Economy activities. Thefore, Faculty Creative Technology and Heritage introduce I-Monsun, it is a private division to catalyse the creative economy development in the country through future model of Sustainable Entrepreneurship Ecosphere (FTKW-SEE). The initiative is our strategic plan to encorrage FTKW graduates to become knowledgeable and skilful entrepreneours as well as for FTKW to contribute in creating job market and shaping the creative economy. This article discusse in how the model work through its several multi-functional entities creates the entire FTKW-SEE Model.

\subsection{Creative Economy Review}

What is Creative Economy? The best example to describe through understanding how to make money from creative ideas (John Howkins, 2003). New ideas, not money or machinery, are the sources of success today, and the greatest source of personal satisfaction.

The creative economy is revitalising manufacturing, services, retailing and entertainment industries. It is changing where people want to live, work and learn - where they think, invent and produce.

The creative economy is based on a new way of thinking and doing. The primary inputs are our individual talents or skills. These inputs may be familiar or novel; more importantly, our creativity transforms them in novel ways. In some sectors the output values depend on their uniqueness; in others, on how easily it can be copied and sold to large numbers of people. The heartlands are art, culture, design and innovation. The creative economy brings together ideas about the creative industries, the cultural industries, creative cities, clusters and the creative class.

Presently, the creative industry is becoming an increasingly important component of modern post-industrial knowledge-based economies. Not only it is thought to account for higher than average grown and job creation, it can also become a vehicle of cultural identity that plays an important role in fostering cultural diversity.

During the last decade, a number of governments around the world have recognized this fact and started to develop specific policies to promote them, including Malaysia. A sector, which was once considered arginal and receiving limited attention from researchers, has today contributed to a significant amount of many nation's GDP, with some cntries including Malaysia breaching 5\% of GDP, with the US taking the number one spot at $11 \%$ of its total GDP in 2010. 
In Malaysia it has been acknowledged that the creative industry is one of the fastest growing sectors in the economy averaging at $11 \%$ per annum over the last five years. This demonstrates creative industry is a key driver for economy and is more dynamic than many of the other sectors in Malaysia (Mukriz Mudaris, 2012). Figure 1 summarizes the common sectorial analysis for Creative Industry.

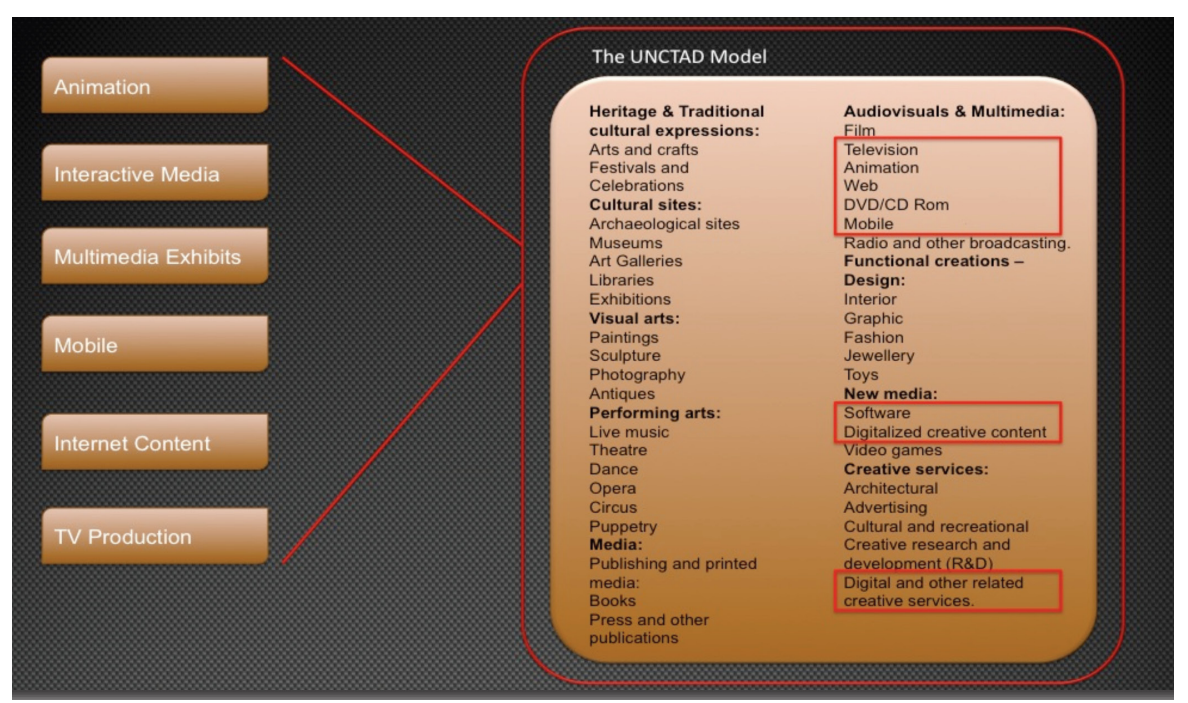

Figure 1: Sectorial Analysis for Malaysian Creative Industry

\subsection{Role of FTKW in Creative Economy}

Creativity is central in the arts and media industry as it provides inputs for all sectors particularly in terms of form and content designs in the global economical circles. This development has given rise to the phenomenon of "creative future" of the 21st Century in which, at the same time, meteoric advancement in science and technology is taking place with the invention of a variety of communication networks and new media where the internet has been, by far, the most important feature of living systems.

The fusion of creativity and technology paves a new path in today's and future's growth and prosperity. The amalgamation of creativity and technology is one of the key ingredients to ensure today's and future's economic success especially by developing internationally competitive products and services. Creative industries, which have their origins in individual creativity, skills and talents, have exponentially contributed to wealth and job creations by ways of generating and exploiting intellectual property. The following list, which 
although by no means exhaustive, sufficiently indicates the vast scope of creative industries: advertising, architecture, the arts and antiques market, crafts, design, designer fashion, film and video, interactive leisure software, music, performing arts, publishing, software and computer services, television and radio.

The growth of creative industry is linked to the rise of cultural industries particularly in all aspects of production, distribution and consumption of the economy and the increase in the influences and interests of services sector. This is directly related to the new economic gravitational dynamism marked by influence and power: Attention Economy/ Gift Economy/ Economy Innovation/ Creative Economy. They are in the forms of informational, global and networking. Generally, creative industries are to be associated with human creation, publishing or production, circulation or distribution, exchange or exhibition, consumption ofgoodsandtoprovideattorney/servicesinordertofeedcultural, artistic, aesthetic, intellectual, and emotional needs and demands of customers in the market. Further in cultural processes such as design aims at bringing out a strong impression in all aspects of life directly affiliated with the consumption of commodities.

Culture is no longer a mere belief and practice in the social life, but it covers all forms and contents of the system and way of human life: ranging from urban design, officials, houses, architecture, statues, transportation and communication systems, through fashion on how clothing identity gives meaning to wearers and spectators, to promotional strategies on how the government manages ecopocial promotional culture in the age of electronic commerce and the mainpulation of barrage of construction and agricultural sectors, entertainment and media in order to meet the needs of economic innovation through creative economic policies. At the moment, there are lack of study indicating the appropriate model of sustainable entrepreneouship ecosphere that able to aspire and excel the glorious Enterpreneourship and Regenerative Economy (ERE) in Malaysia by the manipulation of traditions, heritage, faith and culture so as to be able to potentially dominate the area of creative economy.

Therefore, as promising player in higher education institution, Universiti Malaysia Kelantan , Faculty of Creative Technology and Heritage (FTKW) takes this opportunity to produce knowledgble and skillfull human capital and established the appropriate platform for creative economy sustainability through the Future Model of FTKW Sustainable Entrepreneourship Ecosphere (FTKW-SEE) driven by I-Monsun.

\subsection{I-Monsun}

I-Monsun, Faculty of Creative Technology and Heritage private wing to catalyse creative economy development in the country through future model of Sustainable Entrepreneurship Ecosphere (FTKW-SEE). The initiative is our strategic plan to encorrage FTKW graduates to become knowledgeable and skillfull entrepreneours to help create job marketand shape the creative economy. Basically, l-Monsun consists of two major entities as engines to realize the entire FTKW-SEE success: Monsun Industries and Monsun Academy. 


\subsection{Monsun Industries}

Monsun Industries is a unique platform to catalize the growth of creative economy through sustainable approach creating specific niche areas of product invention and innovation for commercialization. Knowledgeable and skillfull FTKW graduates will become profesional who create product and offer services through this platform.

\subsubsection{Cyberology}

Cyberology is responsible in creating new digital products for customers' consumptions. In a broader concept, Cyberology is essentially the efficient and effective generation and development of ideas through a process that leads to new products. In a systematic approach, cyberologists with expertise in virtual reality technology (VRT), Animation and Ludology, media and robotics design, conceptualize and evaluate ideas, strive for and explore in tangible inventions and digital products. The role of group members is to combine art, science and technology to create new products that other people can use.

The example of cyberology products are virtual models for construction, tourism, graphic, simulation, animation for games, movie, entertainment, performance, information deployment, media for digital journalism, e-book, e-commerce, and robotic for consumer products. Other aspects of Cyberology include cyberspace, cybergogy, cybernetics and anything related to digital and online system in monitoring physical robotic mechanism.

\subsubsection{Heritage}

Industry that manages the historical sites, buildings, and museums in a particular place, with the aim of encouraging tourism and the heritage industry (Collin Dictionary, 2014). Our Monsun Industries also provide a platform to promote any heritage industrial and professional services while preserving the local heritage.

\subsubsection{Artistic}

Artistic is defined as conforming to the standards of art, pertaining to the art appreciation, characteristics of art or artists and showing skills in execution. The establishement of Monsun Industries under I-Monsun is able to create an integrated sustainable artistic industry players, professional, practitioners as well as investors to produce quality products for local and international markets. At the end the platform become an international hub for artistic industries providing the accumulative talents needed by the industries. 


\subsubsection{Creative Technology}

The research, innovation and commercialization of Creative Technology are to combine art, science, and technology or to create new products that other people can use. An appropriate marketing effort should be in place to capture wider market sector. Product design research covers Industrial Design, Services, Software and Physical Product Design. Industrial design is concerned with artistic forms and usability, usually associated with craft designs and ergonomics for massproduce goods. Fashion industry produces creative extravagance and materialistic needs for the people. Visual communication designers, for instance, may run the gamut from initial business ideas to business successes. Fine arts play significant roles in art galleries, museums, theatre, film and crafts, advertising and marketing, exhibition design, publishing and illustrating.

\subsubsection{Architecture}

Ekistics has been defined by scholars (including C. A. Doxiadis) since 1956 as a global science of human settlement (small or large, ancient, modern or future, isolated, in group or regions, examined whole or in constituent parts from all aspects including geographic, economic, social cultural, administrative, legal aesthetic and technological). The notion implies that understanding the interaction between (and within) human groups - shelter, infrastructure and function (job) -- in conjunction with their environment (including built environment) directly affects their well-being (individual and collective). In conjunction with this, the sub-cluster's main function is to create research opportunities that can produce innovative and sustainable design and management through the adoption of mega trends and cities concept with heritage and entrepreneurial characteristics as a strategic niche area.

\subsection{Monsun Academy}

Monsun Academy is another important platform created under I-Monsun to catalyse the growth of creative economy through sustainable approach from specific niche areas of professional educational services and consultations through academic diploma and certificate programmes. Knowledgeable and skillfull FTKW graduates are trained in the programmes to become lecturer for diploma programmes and professional certification course to collaborators and partners.

The synergy with our potential partners and colloborators such as Community College, Institute Kemahiran Belia Negara, and Desa Ukir Kayu could create the sustainable ecosystem for industrial and human capital needs toward the development of creative economy. The establishment of the Monsun Academy under I-Monsun is determined to produce the semi-profesional graduates at diploma level in our niche areas acting as feeder college for degree programmes offered by Faculty of Creative Technology, Universiti Malaysia Kelantan. 
Another significant role of Monsun Academy is to act as the National Occupational Skill Standard Certification Centre in collaboration with Jabatan Pendidikan Kemahiran (JPK).

\subsection{Future Model of FTKW Sustainable Entrepreneurship Ecosphere (FTKW-see Model)}

This sustainable model proposes the complete cycle of income generator and entrepreneurship platform through two major integrated entities (Monsun Industries and Monson Academy) to form the entire complete ecosphere model of: 1) Innovation, Creativity and Entrepreneurship (ICE); 2) Student In Free Enactus (SIFE) and 3) Entreprenuership and Regenerative Economy Enterprises (ERE). Monsun Industries concentrates on product and professional services commercialization focusing on local and global markets to generate profit for FTKW, UMK. Figure 2 briefly describes an overview of Future Model of FTKW Sustainable Entrepreneurship Ecosphere (FTKW-SEE Model).

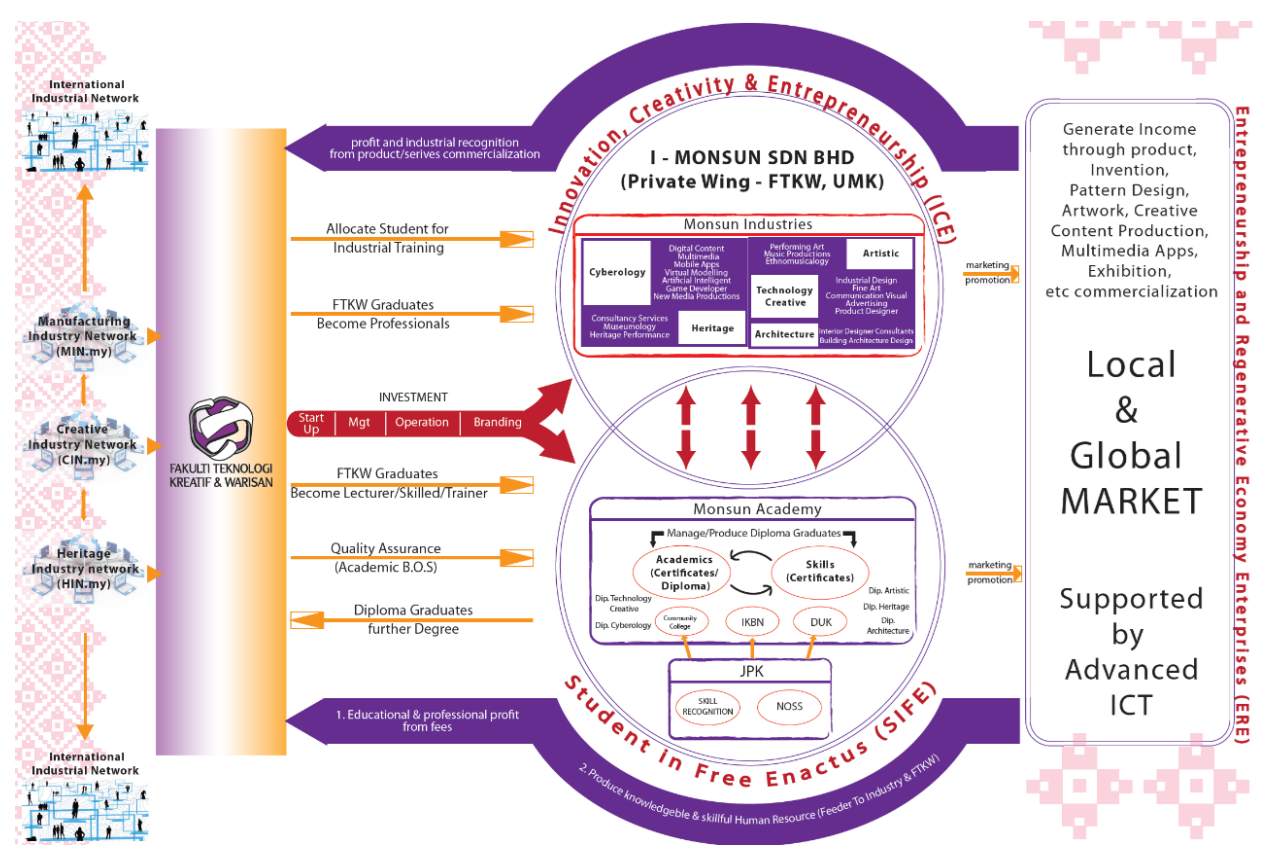

Figure 2: Future Model of FTKW Sustainable Entrepreneurship Ecosphere (FTKW-SEE Model). 
Faculty of Creative Technology and Heritage (FTKW) will facilitate the establishment, planning and implementation of I-Monsun through the proposed model (Future Model of FTKW Sustainble Entrepreneurship Ecosphere (FTKW-SEE Model)). FTKW will be responsible to manage the funds from central (UMK) and other various agencies toward the establishment of I-Monsun.

As shown in figure 2, the future model of FTKW Sustainable Entrepreneurship Ecosphere consists of the integration of the following ecosystems:

5.1 Innovation, Creativity and Entrepreneurship (ICE)

Monsun Industries are responsible to execute the implementation of this ecosystem. Through this platform, FTKW graduate could contribute their knowledge and skills of our niche areas to produce, innovate and promote their product and services to the real world initiated by Monsun Industries. At this moment, Monsun Industries specialises in Cyberology, Creative Technology, Heritage, Artistic and Architecture/Ekistics. Figure 3 illustrates an overview of the entities in Innovation, Creativity and Entrepreneurship (ICE).

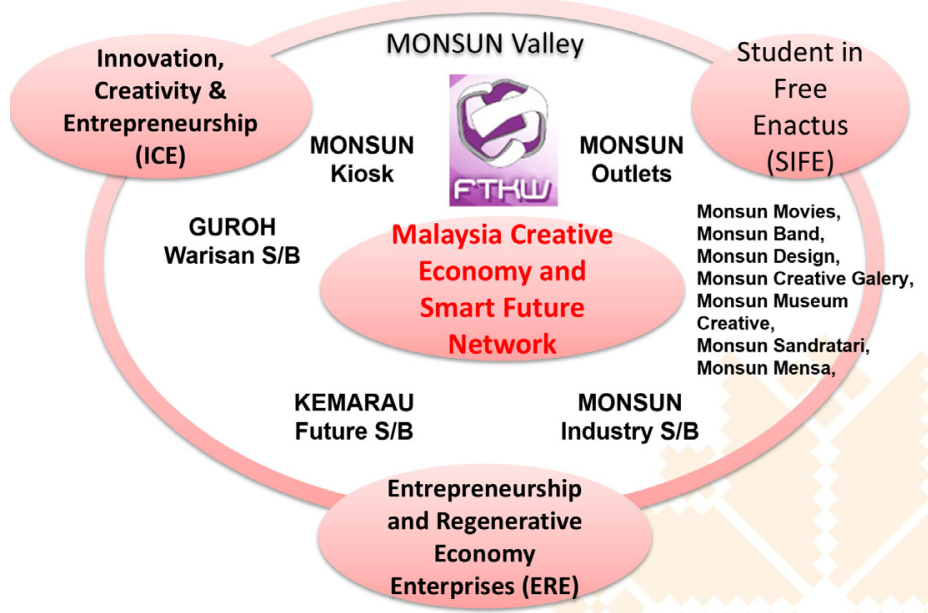

Figure 3: An Overview of Innovation, Creativity and Entrepreneurship (ICE) Entities 


\subsection{Student In Free Enactus (SIFE)}

Monsun Academy is responsible to execute the implementation of this ecosystem. Generate Income through sustainable creative economy eco-system via encouraging Vocational Skills/Knowledge Development, strengthening Programs/Enhance Quality of Students/Create web of networks, strengthen the Educational Contributions at National \& International levels to shape the creative economy \& industrial landscape. Besides the contribution to academic human capital, this ecosystem also contributes to industrial professional services. Figure 4 illustrates an overview of Student In Free Enactus (SIFE).

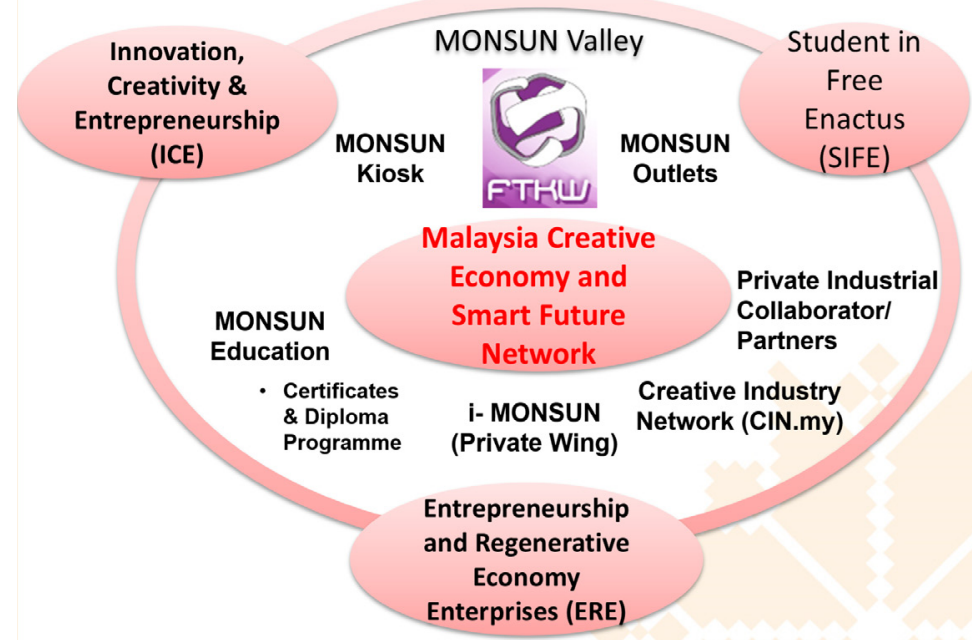

Figure 4: An Overview of Student In Free Enactus (SIFE) Entities.

\subsection{Entreprenuership and Regenerative Economy Enterprises (ERE):}

Our effective entrepreneurship and commercialization strategic model is capable to catalyse the development of creative economy locally and internationally. The entrepreneurial activities and products commercialization could offer more job opportunities in the market and utilise the human capital for industrial growth. FTKW entrepreneurial strategy could prosper and sustain the creative economy eco-system locally and internationally through its unique accumulative strengths of expertise, management and strategies. Figure 5 illustrates an overview of Entreprenuership and Regenerative Economy Enterprises (ERE).

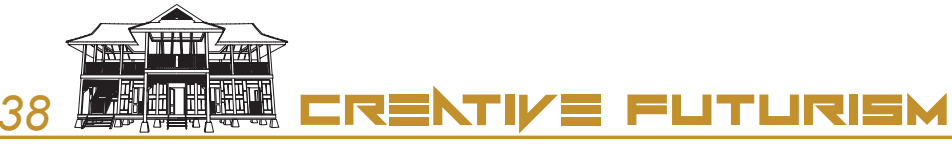




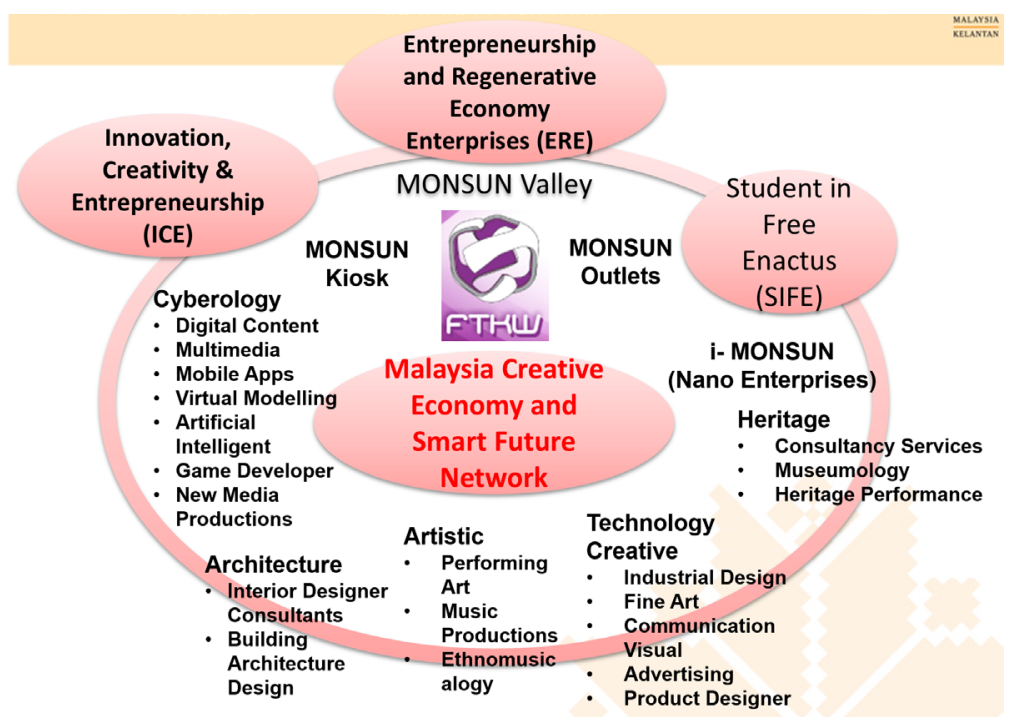

Figure 5: An Overview of Entreprenuership and Regenerative Economy Enterprises (ERE)

\subsection{Virtual Industrial Network Integrated Platforms}

FTKW is also responsible to facilitate the industries of Virtual International Networking Linkages (VINL) through the establishment of Virtual Industrial Network Platform such as CIN.my, HIN.my and MIN.my. The main purpose of this platform is to become the single integrated platform for our niche focused industrial networks such as Creative Industry, Heritage Industry and Manufacturing Industry. This platform is mainly created as an integrated sphere of industrial network for related industry players, investors, regulators professionals and etc. CIN.my focuses for examples, on Creative Industry community, HIN.my focuses on Heritage Industrial Community and MIN.my targeted on Manufacturing Industrial Community.

\subsection{Conclusion}

Creative industry growth is in relation to the rise of cultural industries, recognizes significant knowledge in all aspects of production, distribution and consumption of the economy, and fosters an increase in the influence and impact in services sector.

The success of FTKW-SEE Model and its entrepreneurial efforts depends highly on the commitment of the management and members. The entities introduced in this model will catalyse the sustainable creative economy ecosystem proactively to achieve our strategic visions and missions. Collaboration from 
both within and outside of UMK is essential in ensuring the smooth sailing of this visionary endeavour. The investment for the creation of I-Monsun aims to generate income from both sources, Monsun Industries and Monsun Academy. Monsun Industries gain revenue from industrial recognition through product and service commercialization. On the other hand, Monsun Academy generates income from educational and profesional fees from diploma programmes and training certification. The I-Monsun: FTKW-SEE Model is drawn to ensure the relevancy of creative technology as well as to realise the dream of turning east coast into a hub for Malaysian Creative Economy in the near future.

FTKW strategize specific directions for our graduates to support and embark entrepreneurial activities. Toward the growth of Creative Economy locally and internationally, FTKW has drafted the complete Sustainable Entrepreneurship Ecosphere (FTKW-SEE) as a model for our graduates to move forward as key players and catalysts in the industries.

Furthermore, through our effective entrepreneurship and commercial strategic roadmaps, the proposed system is predicted to be able to catalyse the development of creative economy locally and internationally. The entrepreneurial activities and product commercialization are capable to offer more job opportunities in the markets and to utilize the human capital for industrial growth in the country. FTKW entrepreneurial strategy could prosper and sustain the creative economy eco-system locally and internationally through its unique accumulative strengths of expertise, management and strategists.

\section{References}

John Howkins, 2010 (Source: http://www.creativeeconomy.com/thebasics.htm)

MyIPO-WIPO Survey 2009, MDeC Creative Content Baseline Study.

Mukriz Mudaris, 2012, Creative Industry Sectorial Analysia.

Collin Dictionary, 2014 (Source: http://www.collinsdictionary.com/dictionary/english/heritage-industry). 